\title{
DEPICTION OF WOMEN IN NINETEENTH CENTURY AMERICAN AND BRITISH FICTION
}

\author{
Dr. Naresh M. Solanki
}

\begin{abstract}
It was time of nineteenth century when women writers used to have male pennames for publication. Theme of marriage and society were prevalent in both American and British society. It was a microcosm of its own as women readers used to write about their life through the eyes of women writers. This phenomenon is historical as it stands between Mary Wollstonecraft, arguably the first feminist thinker and Virginia Woolf, arguably the most famous one. Changing times in the second half of nineteenth century was affecting the sensibility and religious clutches on society. It was also affecting notions of patriarchy. Writings of the time ought to reflect that.

However, author also presumes a gender of her or his own before writing. That makes her or his gendering of character political and biased. But honest portrayals are important for examining depictions of women in a particular time. This paper aims to analyse two popular writers of the age, a female and a male, to understand the changing notions regarding patriarchy. American novelist Louisa May Alcott (1832-1888) have been written important social novels like novel Little Women (1868) and its sequels Little Men (1871) and Jo's Boys (1886). Her novels features cast of female characters from the contemporary times. Arthur Conan Doyle, creator of Sherlock Holmes, was a British writer writing detective fiction who used to portray his contemporary society. He also uses female characters in her stories. This paper aims to study works of both novelist employing methodologies of close reading and comparative literature to see how depiction of women in nineteenth century America and British fiction changes and what are the reasons for it.
\end{abstract}

Keywords: Women's writing, Nineteenth Century literature, Little Women, Sherlock Holmes

\section{$\underline{\text { Introduction }}$}

Louisa May Alcott was an American novelist whose reputation rests on her domestic fiction especially on novel Little Women (1868). It has been considered a successful work both commercially and critically. It depicts life of four sisters in nineteenth century. It follows a simple plot where these characters faces problems and deals with them in their way and learning from it. author has portrayed them depicting different kind of personalities. Mag is a wise girl. Jo, who is considered protagonist of the novel, is called a 'tomboy'. Beth is shy. Amy is youngest of the siblings. Their lives are tested with separation of beloved, social conditions, their personal flows and of course by patriarchal mindset of the time. 
Sir Arthur Conan Doyle was a popular British writers whose science fiction and detective novels are pioneering in the genre. Characters created by him have become architypes in the genre fiction. Sherlock Holmes stories are his best known work. The detective and the narrative are male but these stories has recurring cast of women characters.

Depiction of women as characters is the focus of this paper. Women character are often in struggle for their positions in a patriarchal society. Underlying themes in works often denotes position of women in the hierarchical power centred structures. This paper aims to identify those underlaying themes via close reading of depiction of women by both male and female writers from nineteenth century.

Depiction means 'to represent' as per Cambridge dictionary. Representation of anything or anyone in work of art is called depiction. This representation has a counterpart in reality and it stays as it is. This representation is twice removed from reality as per Plato. As this paper has nineteenth century women as the object of depiction it will take 'real' conditions of nineteenth century women in consideration. That is reason why two authors, one male and one female has been chosen for this study. It can denote how subjective perspective and objective perspective plays in the depiction. Also, depiction of women as 'what' is the question that studies like this should inquire into. Another important question is of 'how' which can tell us about writers' strategies of depiction.

\section{Gender as Device}

Writing is not lonely activity, especially when a writer has particular readership in mind. Writers use various devices and tropes to further the story and in doing that they either follow or subvert conventions. This also marks changed in particular theme or architypes. For example 'love' as theme has been part of literature from medieval times, but depiction of it differs from era to era. Modernist writers like Marquez and Borges. Modern comedy genre uses love to mock behavioural aspect of present social life like dating. A literary device is a special technique used by writer to create a special effect. What this special effect can be is debatable but one can perceive them as out of conventions. For example, 'unreliable narrator' is used as a device to conceal narrator's motive or , as in The Murder of Roger Ackroyd, to conceal an important plot point till climax.

When an author takes gender as device to tell stories, he or she has some political or sociocultural agenda consciously or unconsciously. Characters depicted by both writers shows some similarities and differences. These differences are marker of change in cultures, namely British and American. Other than that it denotes different world view of both authors.

\section{The Mother Figure}

In Little Women, Mrs. March is literally mother of titular sisters. However, 'mother figure' as literary architype is different from literal role of being a mother, even as far as to exclude biological connections. Alcott depicts the character of Mrs. March as mother figure none the less. So she creates relations that are 'normal' and very much easy to recognise. Her strategy is to create a background for her tales of sisters. Mrs. March gives them umbrella of warmth as they grow up. She is the guiding light for sisters on pathway to society. 
Sherlock Holmes stories feature two characters frequently. One is Watson who is narrator of tales and other is Mrs. Hudson who is house owner of Holmes' apartment and also takes care of him. Here we see no biological connections between protagonist and mother figure but she becomes this figure by her care for the Sherlock. For example, Watson writes,

"Mrs Hudson, the landlady of Sherlock Holmes, was a long-suffering woman. Not only was her first-floor flat invaded at all hours by throngs of singular and often undesirable characters but her remarkable lodger showed an eccentricity and irregularity in his life which must have sorely tried her patience. His incredible untidiness, his addiction to music at strange hours, his occasional revolver practice within doors, his weird and often malodorous scientific experiments, and the atmosphere of violence and danger which hung around him made him the very worst tenant in London. On the other hand, his payments were princely. I have no doubt that the house might have been purchased at the price which Holmes paid for his rooms during the years that I was with him. The landlady stood in the deepest awe of him and never dared to interfere with him, however outrageous his proceedings might seem. She was fond of him, too, for he had a remarkable gentleness and courtesy in his dealings with women."

(https://en.wikisource.org/wiki/The Adventure of the Dying_Detective)

Here, Mrs. Hudson is presented as a bearing Landlady which no landlord would show towards an annoying tenant like Holmes. So, her tolerance and caring points towards her being the mother figure to Holmes. However, her intrusions doesn't affect character of Holmes as does the character of Mrs. March to sisters.

\section{The Kind Figure}

Annie, who features in The Naval Treaty is a kind lady. So is Beth, the shy sister. Being kind is essential feature of being a 'lady' as Victorian notion dictates. Here both writers affirms that image by portraying ladies as kind.

"You can imagine the state of things here when they were roused from their beds by the doctor's ringing and found me in this condition. Poor Annie here and my mother were broken-hearted. Dr. Ferrier had just heard enough from the detective at the station to be able to give an idea of what had happened, and his story did not mend matters. It was evident to all that I was in for a long illness, so Joseph was bundled out of this cheery bedroom, and it was turned into a sick-room for me. Here I have lain, Mr. Holmes, for over nine weeks, unconscious, and raving with brain-fever."

(https://en.wikisource.org/wiki/The Memoirs_of_Sherlock_Holmes/The Naval_Treat

On the other hand Beth serves larger purpose. She described as kind, gentle, sweet, shy, quite and musical. She serves as direct contrast to character of Jo who is rebellious. Beth is already the 'lady' by Victorian standard. That makes her character the idealistic social framework from where the author wants to portray protagonist as rebellious, thereby creating a new figure.

The Angry Figure 
Speaking of Jo, She is the 'point' Alcott wishes to make by this novel. Character of Jo defies the conventions laid upon her gender and tries to break free. She is the angry figure Alcott shows as a model for young girl instead of notions propagated by society. Her actions also speaks for her attitude. She is a responsible girl.

"'I let the sun go down on my anger; I wouldn't forgive her, and today, if it hadn't been for Laurie, it might have been too late! How could I be so wicked?" said Jo, half aloud, as she leaned over her sister softly stroking the wet hair scattered on the pillow. As if she heard, Amy opened her eyes, and held out her arms, with a smile that went straight to Jo's heart. Neither said a word, but they hugged one another close, in spite of the blankets, and everything was forgiven and forgotten in one hearty kiss."

(Little Women, Chapter 8)

Her responsibility towards other sometimes even ignores image a of self. She is already described as 'tomboy' in the novel. But her hair is beautiful. She sells them to get money for mother. She sacrifices her precious hair to help her family. Her rebelliousness is filled with kindness.

Arthur Conan Doyle fails to capture such dynamics of being a woman in nineteenth century. However, he also present an alternative model to kind figure with character of Violet Smith in The Solitary Cyclist. She is presented as humble figure at first. As she is beautiful she has many suitors. One of them follows her when she is in bicycle. Here first Watson's narrative suggest that sexual harassment is price of being beautiful, which is shocking. But Holmes' character treats the matter seriously. Violet once turns her bike towards her stalker and causes him to flee. This bravery is no less than Jo's bravery of going out in bad weather and calling doctor for Beth.Character of Kitty Winter in The Illustrious Client seems to rebel against the Victorian model of womanhood.

\section{The Antagonist Figure}

Portraying a woman as antagonist can have different functions. Author may derogate the status of being a woman by making her an antagonist or may give her a depth of character like Shakespeare did with lady Macbeth. This all leads to inspection of Little Women as it is in domestic setting and is about rebellious Jo growing up. But as one critic says, "There really isn't any villain in Little Women - no scheming bad guy plotting the downfall of the sisters, no evil genius, and no childhood rival. Instead, each of the girls slowly but surely conquers her own personality flaws. So if the protagonist is Jo March, well, so is the antagonist - she's her own worst enemy." Her own demon hunts her throughout the novel and that makes the novel compelling and serious.

For Conan Doyle as he was writing detective fiction he could take liberty in portrayal to be little stereotypical. So, he presents woman as antagonist in some stories. Irene Adler is famous for being the criminal who could deceive Sherlock in his own game. Watson says, "“'And that was how a great scandal threatened to affect the kingdom of Bohemia, and how the best plans of Mr. Sherlock Holmes were beaten by a woman's wit. He used to make merry over the cleverness of women, but I have not heard him do it of late. And when he speaks of Irene 
Adler, or when he refers to her photograph, it is always under the honourable title of the woman." Here the title of woman is representative of her race. Conan Doyle gives woman more intellectual skill, while making her criminal. 


\title{
Bibliography
}

Alcott, Louisa May, 1832-1888. Little Women. Melbourne ; London ; Baltimore :Penguin Books, 1953.

Doyle, Arthur C. The Adventures of Sherlock Holmes. New York: A \& W Visual Library, 1975. Print.

Nazeri, Zahma. A Comparative Study of the Image of Joe March in the Movie Adaptations of Little Women

Plummer, Jesics. 10 Fascinating Women in the Sherlock Holmes Canon (Who Aren't Irene Adler), Booksriot.com

The International Conference on Current Issues of Languages, Dialects and Linguistics.

\author{
Dr. Naresh M. Solanki \\ Head, \\ Department of English, \\ Dr. Subhash Mahila Arts, Commerce and Science College, Junagadh \\ nareshsolanki456@gmail.com
}

